\title{
Geography in Ireland in transition-
}

\author{
some comments \\ Introduction \\ Mary Gilmartin \\ Department of Geography, University College Dublin
}

The publication of Rob Kitchin's commentary on the state of Geography in Ireland in the sixtieth anniversary issue of Irish Geography has opened the possibility for a broader, public dialogue about our discipline. This forum represents a continuation of this conversation, with its focus on a variety of theoretical, institutional and personal concerns about Irish Geography.

When Rob's commentary was published, I solicited a range of responses. In asking people to respond, I was conscious of ensuring that there were contributions from women and from men; from junior and from senior academics; from people with experiences of studying and working inside and outside Ireland; and from human and physical geographers. There are, of course, gaps in the make-up of contributors. Despite my efforts, there are no commentaries from academics based in Northern Ireland. In addition, academics who have worked in Irish Geography for a long period were significantly less likely to contribute than their lessestablished colleagues. My instructions were minimal. I asked contributors to respond to what they saw as the significant points included or excluded from Rob's commentary, in around 1000 words. My editorial interventions were mostly related to reducing the length of the responses.

A range of significant themes is highlighted and discussed in the pieces that follow. For some of the contributors, the nature of geography - within Ireland and more broadly - is at question. The responses from both Ulf Strohmayer and from Anna Davies and David Taylor are particularly concerned with this issue. Others focus on the broader institutional constraints and opportunities within the Irish education sector: this is apparent in the pieces by Gerald Mills and Denis Linehan. The issue of the involvement of geographers in broader public debates exercises David Nally in particular, but also Ulf Strohmayer. Responses by Pádraig Carmody and Mark McCarthy insist that we consider geography in broader contexts: in a range of institutional settings within Ireland, and in comparison with geography in the US. Seamus Grimes argues that we need to provide a firm intellectual basis for the practice of geography within Ireland. And Caitriona Ni Laoire, in a wide-ranging response, points out the need for a broader and more inclusive understanding of the Irish Geography community, particularly in relation to issues of gender and contractual status.

I hope this forum will provide constructive grounds for thought and debate for those of us working in and/or concemed with the current state and future of Irish Geography. I am grateful to Rob Kitchin for initiating the debate, and to Joe Brady for encouraging the publication of this series of responses. I am also grateful to the contributors who so readily agreed to respond to Rob's commentary. Their willingness to participate in this forum and their range of concerns is evidence of a vibrant community. It would be productive to continue the dialogue in a more inclusive forum-perhaps at the forthcoming 2005 Conference of Irish Geographers in Galway.

Other responses draw directly on personal experiences.

Irish Geography, Volume 37(2), 2004, 121-144. 


\section{UIf Strohmayer \\ Department of Geography, NUI, Galway}

Being asked to comment on someone else's thoughts is always an honour and an opportunity. In the present context, however, it is the general invitation itself that becomes an event by aiming to establish an official forum for debate. This move towards more formal and visibly public forms of exchange, to run alongside the many informal ways of communication that have characterised Irish Geography, is itself a sign of change, a sign, more precisely, of a community that is beginning to outgrow the niche it has occupied for the longest time. I had the pleasure of reading 'Geography in Ireland in transition' before it went to press and welcomed, above all, the institutional thrust of the argument presented by Rob. In a time when many departments are vastly under-staffed, under-resourced and threatened with institutional restructuring, I was happy to be reminded of the larger picture and how it might affect our collective ability to create geographical knowledges, be it in the classroom, on the conference circuit or in published forms.

Re-reading the short comment in preparation for this 'reply', I still find myself agreeing with most of the points raised ? yes, Irish Geography has grown; yes, it has become more 'visible;' and yes, it has attracted increased amounts of funding since the start of the new millennium. As anyone who has attended the annual Conference of Irish Geographers (CIG) or the Irish Postgraduate Training Consortium (IPTC) on a regular basis will be able to attest, Rob's insistence on a series of quantitative quantum leaps within Irish Geography is also more than matched by an increase in the diversity and innovativeness of postgraduate work especially now conducted in Ireland.

What Rob failed to acknowledge ? perhaps for perfectly legitimate strategic reasons ? is that the very reasons behind some of the recent successes within Irish Geography are also to blame for some of the 'challenges' he laments. Chief amongst these latter appears to be the vision, shared by many, of a community of geographical scholars working either in tandem or within a common frame of references. But is this a realistic vision, especially in light of the celebrated 'professionalisation' of Irish geographical practices? Yes, most geographers working in Ireland will welcome the increase in international profile for the kind of research we produce, but perhaps we should acknowledge that this very increase in profile and visibility is also likely to create centrifugal forces that might easily pull the geographic community apart, rather than unite it. Hence, for instance, the lamented lack of available support by staff members for, say, the IPTC: with increased teaching and supervisory loads, funding applications to finish or conference attendance to juggle against family and other commitments, few are those ready, willing and able to take on 'additional' or 'voluntary' work.

But there's more to this side of the equation: virtually all of the 'successes' invoked by Rob will diversify, rather than unite, the geographic community within Ireland. Those networks that yield quantifiable results in terms of funding or prestige tend to be specialised ones and are often positioned on the margins of the discipline. In this respect, Irish Geography is perhaps becoming more akin to its British and American counterparts where arguably an increasing number of important developments are located in the margins of geographic practices. Perhaps, too, this should not surprise anyone given the all but quaint claims to inclusivity, representational completeness and, crucially, communicative openness that have characterised an older dream of geography as a discipline. This is not the place to lament the demise of that dream (or to celebrate such a development ? to each one her or his vision of 
what is means to be a geographer) but to acknowledge that having our cake ? the unity of the discipline ? and eating it, too ? receive funding and be internationally recognised might not be possible in the medium-term future.

All the more reason, one might say, to applaud Rob for inviting us to think about where we are and where we would like to be in a not too distant future. Indeed. But the landscape he paints of the discipline is a curiously flat one where challenges can and should be met on a personal level. Thus the ? indeed welcome! ? plea for more people attending the annual CIG or engaging in cross border interaction. An increase in engagement, however, will not automatically lead to a less variable community amongst professional geographers working in Ireland. Consider, for instance, the often quite real divergences of opinions about the development of geographical syllabi within departments or the largely unaccountable decisions about whether or not to award funding to a particular individual or project: unexamined ideological differences (about theory, the role and importance of gender, or say the 'desirability' of working with certain colleagues) often play a crucial role in these decisions? and will not be eroded simply by meeting more often. Constructive criticism in public ? and the creation of 'spaces' for such an engagement to take place? would need to become an integral component of such meetings. In other words, it comes as somewhat of a surprise to see the most gifted and skilled builder of networks now working in Ireland not to mention the crucial role of power in the construction and maintenance of geographic communities!

Mention of both 'power' and 'public engagements' allows me to mention a final point curiously underplayed in Rob's initial statement, a point that emerged forcefully in a conversation with my colleague John Morrissey here in Galway about Rob's 'comment'. Arguably the greatest challenge facing Irish Geography today, a challenge barely masked by the successes in undergraduate and postgraduate recruitment, is the willingness of Irish geographers to engage with audiences beyond the narrow confines of academia. Given the eminently public nature of much of the work we do, the relative lack of publicly visible expertise in the Irish media landscape comes as somewhat of a surprise. Think of environmental degradation, global warming, the work done on national and international conflicts, on citizenship, on the role of the EU shaping policies both north and south of the border? there's precious little that geographers could not tackle and so much that we could contribute to Irish civil society! Some of us excel in this public context, but a majority shies away? why?

Yet again, public interventions have always also been characterised by strategic deployments of arguments (as well as by the space granted to any author by an editor!) and Rob's highly appreciated appeal to the geographic community to celebrate ' 60 years of Irish Geography' is no exception to this rule. If it draws increasing numbers of 'us' to engage with one another and to reach out from within the Geographical Society of Ireland to communities ? academic and otherwise ? within Ireland and across the various waters that surround this island, a lot will be gained already. 


\section{Anna Davies and David Taylor \\ Department of Geography, Trinity College, University of Dublin}

'There would be no wars if everyone was taught how to dance. Why is so much time wasted at schools teaching subjects like...subjects like Geography?'.

(Michael, Dancer)

While Michael's statement was no more than an unfortunate selection of subject (he did not know he was talking to a geography lecturer [Anna] at the time) such declarations, particularly when viewed in the context of Rob Kitchin's comments in the previous issue of Irish Geography on the challenges facing our discipline, provide an opportunity for thought about the nature and purpose of geography. Rob also, and quite justifiably, comments on the recent successes of geography in Ireland. He may even underplay those successes. The British Academy, Combat Poverty, the Irish Research Council for Science, Engineering and Technology (IRCSET), and the National Geographic Society (US) can be added to the list of agencies cited by Rob that are currently funding research in departments of Geography in Ireland, and there are no doubt more. As a result of geographers being able to access multiple sources, geography has one of the broadest research funding bases for any discipline: not only does this reflect the widespread appeal of different aspects of geography among those providing research monies, it also provides some insulation against the vagaries of any one source of research finance in the future. Thus although funding from the IRCHSS may have been capped in recent years, geographers have been able to tap additional and new streams of support for research. And more support for research is likely to be available from within institutions in the future, because research activity will receive credit in new generations of resource allocation models that are now being considered, along with numbers of undergraduate and postgraduate students. Furthermore, we think that geographers are playing a much more active role on international advisory boards and committees, including the editorial boards of international journals and panels that evaluate the quality of research and research grant applications, than is suggested in Rob's article. Thus as a community we are far more than simply following in the footsteps of others in order to provide a training in and understanding of geography: through the research that we do, by disseminating the results of this research, and by evaluating the research efforts of others, we are exerting an influence over the development of the discipline within and beyond the island of Ireland.

But are all these successes enough? We may be influencing geography and geographers, and we are certainly appealing to new students and to research grant awarding agencies to the extent that we all now face excessively high work loads, but have we managed to convince the general publics in Ireland of the added value of geography at university? The comment from Michael that opened this response suggests that the mainstreaming of an awareness of the nature and value of geography still has some way to go. Lots of questions naturally follow this last sentence, not least of which is, if there is still some way to go, which route should we take?

Being tested on our sense of direction or trying to overcome the low opinion that some hold for geography when we meet people for the first time may be irritating, but that irritation is only justified if we in the geographic community are secure in our own conviction of what geography is about and have clearly and widely articulated that geographic purpose. Are we currently doing this? The answer is probably not. However following Sauer, reflections on such issues are essential for geographers because 'attempts must be made from time to time to give orientation to ourselves along a common course' (1941: 1) given the breadth of the 
discipline. Being clear about what geography is and its contribution to wider society may be particularly important at present because, as Rob noted, the proposed restructuring of many universities in Ireland will inevitably see geography relocated within the new arrangements of institutional govemance. A worse case outcome of restructuring is that future Michaels may not even acknowledge geography as a 'subject'. A clearer identification and articulation of a common core for geography could help to ensure that the future orientation of the subject is dictated by the geographic community, rather than imposed from above in the general milieu of academia." Here, therefore, we are arguing for greater unity in the diversity that characterises geography - for colleagues to take up the call for 'building bridges between geographers' in order to 'construct some kind of shared future for the discipline' (Kitchin, 2004: 19) - and for geographers in Ireland actively to project this view beyond the discipline and the shores of these islands. We believe that this approach is more likely to ensure the long-term future, vitality and relevance of a discipline that in many institutions may soon no longer be able to call upon the protection afforded by current academic structures.

We should not be afraid of the future, but neither should we be complacent. Occupying the inherently interdisciplinary niche at the interface between sciences and humanities, Mackinder's 'Geographical Experiment' (Matthews and Herbert, 2004: x), has encouraged diversification and specialisation. Thus geographical research and praxis in Ireland is diverse and dynamic, but is it organised and cohesive? It is true that geographers have been successful in attaining research funds from a variety of sources, but how often is that work explicitly recognised externally as geography? Indeed, how much of the research (and teaching) that we do is explicitly geographical? Often research by geographers is published in forms that target particular audiences that are not necessarily linked to the discipline. Simply to assume that people, in academia and among the general publics, will see these efforts as geographical is probably naive. The common popular understanding of geography does not do justice to the substantive and technical knowledge within the discipline and we will continue to be sold short (as geographers) unless we convince people otherwise. Bringing attention to the work of the discipline does not require an evangelical geographical community or a particular academic structure, but it does at very least demand that geographers do - and are widely seen to do - good work and that geographical endeavours are labelled as such.

So which route? If the geographical community, in the present turmoil of academic restructuring, claims rights to the continuing endurance of geography as a discipline then there are concomitant responsibilities to perpetuate the discipline not only through active participation in seminars, conferences and curricula development, but also by highlighting the distinctiveness of geographical research. A starting point would be to encourage all members of the geographic community to debate openly and frequently with each other the nature of geography and the research that is being carried out under its name. There have been, of course, numerous internal debates in recent years about the divisions within the discipline particularly between physical and human geography - and these have tended to overshadow discussions of commonality, what Sauer describes as our 'common course'. Finding the time and the place for more debate is, of course, not easy but it is nonetheless something that we feel needs to be given attention. It may be that geography through taking the evolutionary path into diversification and specialisation has negated its very existence as a distinct discipline. One hopes not. Nonetheless such a position for geography cannot be rejected without a clear and convincing case being made for its continued existence. From our perspective, geography, with its unique location on the boundaries of natural and physical sciences, deserves to be sustained because the issues of scale, place and the interactions 
through time between people and their environment, central to the geographical project, are as crucial now as they have ever been. There needs to be a visible degree of unification through this core geographical purpose and this requires critical dialogue within the geographical community rather than confrontation (or worse silence), and a definite effort to communicate the role that geography can play, as a hub, in interdisciplinary research and policy initiatives. Geography as a whole, through unity in diversity, has a gestalt value that is more than the sum of its individual specialisms and if emphasis is placed on unifying themes 'geography will make greater disciplinary and inter-disciplinary contributions to knowledge and society, thereby fulfilling its destiny amongst the constellation of disciplines' (Matthews and Herbert, 2004: 388).

The right path may, along the way, require the development and maintenance of a firm, common core of explicitly geographical activities. A once-a-year workshop, held over a weekend and at a time that did not compete with either the Conference of Irish Geographers or the Postgraduate Training Consortium meeting, might facilitate cooperation between geographers. Field meetings are another possibility, although we recognise that not all geographers place equal value on fieldwork, as are shared research seminar and teaching programmes. And when it comes to research seminar and conference programmes, rather than taking the absence of particular aspects of geography as a reason to proliferate alternative seminar series or specialist conferences, why not bring such debates to existing geographical fora? A sense of isolation through specialisation in academic units with relatively few staff and researchers is perhaps inevitable, but retreating even further into specialised communities without ensuring strong links to the central core of geography may prove far more threatening to the long-term sustainability of the discipline than academic restructuring. A lack of common core or disciplinary identity not only impacts levels of awareness of what geography actually is outside the discipline, it may also lead to misconceptions of each other's geographies and lost opportunities for dialogue, debate and fruitful collaboration. As discussed at the recent International Geographical Union Conference in Glasgow what is needed is more not less conversations across the internal divides within geography for if we are constantly looked outward we may forget where our disciplinary home is. This is not necessarily a huge task for as Abler et al. (1992: 401) suggest 'the ends of the geographical universe are not as distant from each other as many of our geographical brothers and sisters are wont to believe'.

In conclusion, Rob is right to point to the successes in geography in Ireland since 2000 (and before) and to the challenges that face geographers on the island today and in the future. A worrying feature has emerged over time, however, which is not covered in Rob's comments: while geographers at present need little convincing of the relevance and significance of their discipline (the evidence is all around to the eyes of a geographer), and therefore its conservation value, many outside the discipline (and not just Anna's dance partner) remain less than fully convinced. Forming a coherent view of what geography is and how and where it can contribute to society that is widely shared among geographers and actively promoting this view beyond the discipline is, we feel, the way to ensure that geography continues to play a critical role in explaining the world in which we live and in so doing continues to attract interest from students and funds from research grant awarding bodies. 


\section{References}

ABLER, R., MARCUS, M. and OLSON, J. (1992) Geography's inner worlds: pervasive themes in contemporary American geography. New Brunswick, NJ: Rutgers University Press.

MATTHEWS, J. and HERBERT, D. (2004) Unity in Geography: prospects for a discipline, In: Matthews, J. and Herbert, D. (eds) Unifying Geography: common heritage, shared future. London: Routledge, 369-393.

SAUER, C. (1941) Forward to historical geography, Annals of the Association of American Geographers, 31(1).

\section{Caitríona Ní Laoire \\ Department of Geography, University College Cork}

Rob Kitchin's recent commentary has provided us with a timely opportunity to reflect on the current state of Irish Geography. As outlined in his piece in Irish Geography (2004), the state of the discipline at the start of the millennium is in many ways extremely healthy. Undergraduate numbers remain high, postgraduate numbers are strong, more research funding than ever before is being availed of by geographers, and the general profile, interaction and mobility of geographers is high. However, he also highlights the increased work pressures on geographers as a result of such developments in light of the paucity of new appointments and the recent contraction in research funding. Geographers, like most other academics, now have to balance teaching with greater demands for extemally-funded research activity, high administration loads as well as the demands of increasingly marketdriven universities.

As Rob rezognises, his commentary is situated, as is this one. Perceptions and experiences of these issues will vary according to where one is situated within the geographical community. What I hope to do in this short commentary is to provide another, perhaps slightly different, perspective on the current state of Irish Geography, as a contribution to the healthy dialogue that Rob has called for in his piece. While I recognise the importance of such key issues for Irish Geography as the north-south divide, and the persistent human-physical divide, my comments in this short piece centre on four other key areas: gender, theory, contractual status and community.

Firstly, it seems to me that one of the most important and positive changes in the discipline of geography in Ireland in recent years, which was not mentioned in Kitchin (2004), is the increased participation of women. This is evident, for example, in the increase in the numbers of articles authored by women in the pages of Irish Geography. During the 1989-2001 period, 24 percent of articles in the journal were single-authored or lead-authored by women (Ni Laoire and Linehan, 2002). In contrast, during the period from 1944 to 1988, only 7 percent were written by women (Storey and Ketch, 1989). Numbers of female academic staff in Geography departments on the island have also risen - from the paltry figure of just two (four percent) of the approximately 50 full-time academic staff members in 1989 (Storey and Ketch, 1989), to an estimated 34 (28 per cent) of the 122 full-time academic staff members in 2004. (The 2004 figures are based on information provided on departmental websites at the time of writing, and are therefore prone to error. They include teaching and research staff). Clearly, women are still severely under-represented, but the rates of inclusion are improving, and compare favourably with those in the academic sector as a whole in Ireland (Egan, 1994). 
This is related to a shift towards a more gender-aware discipline in Ireland than in the past. Although gendered geographies are still in a minority in the discipline in Ireland, it is a growing and vibrant body of research, as demonstrated by the recent themed issue of Irish Geography, and by the number of papers on issues of gender and sexuality presented at recent Conferences of Irish Geographers (CIGs). In terms of both intellectual direction, and discipline membership and leadership, Irish Geography is still characterised by gender inequality, but is clearly shifting towards greater gender balance and awareness. This is surely one of the most important developments in the history of the discipline, and merits recognition as such.

This can be situated within a broader theoretical shift within human geography in Ireland, towards a greater recognition of the situated nature of geographical knowledge and the need to destabilise meta-narratives - the 'cultural turn' as mentioned by Rob. The proliferation of new Irish research in social, cultural and economic geography associated with this is very exciting. However, to represent it as a paradigm shift from empiricism to theoretically informed research may be an over-simplification, as it would imply that Irish Geography prior to the influence of the cultural turn was a-theoretical. Of course, this overlooks a wealth of theoretically-driven Irish geographical research, from Anne Buttimer's contributions to humanistic geography to Jim Mac Laughlin's on world-systems theory (to take just two, slightly different, examples). Irish geographical research in the past, as at present, has been influenced by many different overlapping theoretical currents, and to characterise it as a homogeneous body of research is to deny this heritage.

The third area that I wish to comment on is contractual status. Rob makes the point that one of the key changes in the discipline in recent years is the increase in numbers of postgraduate students and postdoctoral researchers. Although he does recognise that this increase represents in many ways a success of the discipline, he also views it as part of the problem of increased workloads for 'professional geographers'. Inevitably, increased numbers of postgraduate students does create new work for supervisory staff, but this is not the full story. In fact, postgraduates and postdoctoral staff make a massive contribution to teaching, administration and general research activity in departments across the country. Departments are coping with the lack of funding for additional lecturing staff in part through employing an army of part-time staff, from among the postgraduate, postdoctoral and research communities. This contribution is not always recognised. Furthermore, as Rob does recognise, the health and vibrancy of recent CIGs is due in no small part to the contribution of this community. The increase in numbers of postgraduate students and postdoctoral staff conducting geographical research in Ireland can only be viewed as a strength rather than a challenge, through their contributions to research, teaching and to the health and vitality of the professional geographical community in general. One of the main challenges for this group, and therefore for Irish Geography as a whole, is the lack of opportunity to develop research careers in Ireland, which is not helped by the recent contraction in research funding.

My final point relates to the question of a geographical 'community'. Rob's piece seems to distinguish between two different definitions of a community of Irish geographers: one, a 'wider, active geographical community', as represented by the attendance at CIGs, for example, and the other, a narrower community of 'professional geographers'. This is an interesting distinction, perhaps representing an ongoing shift in emphasis from the latter to the former. It is clear that the core of the community has changed enormously from being the preserve of a small group of men, to being a much larger and more gender-balanced group. 
Also, if we accept that all of those involved in geographical research or teaching are included, then it is a community not just of tenured academic staff but also of research staff, contract staff, postgraduates and practitioners. Therefore the issues for Irish Geography are the issues that affect all of these groups, issues such as gender equality and the development of research careers, to name just two.

Rob suggests that for him the term 'Irish Geography' refers to 'geography in Ireland'. I prefer the slightly broader term 'geography in and of Ireland', which could include the work of geographers who are outside Ireland but connected with geographical research on Ireland/Irishness or with the discipline in Ireland in some way. As Rob asserts, Irish Geography has been strengthened enormously by the ongoing development of the CIG and by activities such as the Irish-Geography mailing list and the Postgraduate Training Consortium. These activities, more than any, reflect the nature of the Irish geographical community at present. In other words, the 'wider active geographical community' is comprised not just of 'professional' geographers in Ireland, but also of geographers working in all parts of the academic hierarchy, as well as practitioners, Irish geographers outside Ireland, and other geographers of Ireland and Irishness who are based elsewhere. This open and fluid community, which maintains its connections with a rich Irish geographical heritage, but also looks beyond that, is, I believe, the strength of the discipline at present, and the basis from which it can develop in the future and overcome some of the challenges it faces.

\section{Acknowledgement}

I would like to thank my colleague Piaras Mac Einrí for his helpful comments on an earlier draft.

\section{References}

EGAN, O. (1994) Overview of equal opportunities in third level education in Ireland, In: Egan, O. (ed.) Equality of Opportunity in Third Level Education in Ireland. Cork: National Unit on Equal Opportunities at Third Level.

Ní LAOIRE, C. and LINEHAN, D. (2002) Editorial: Engendering the human geographies of Ireland, Irish Geography, 35(1), 1-5

STOREY, D. and KETCH, C. (1989) Where are the women? Some thoughts on the role of women in Irish Geography, Chimera, 4, 25-30.

\section{Gerald Mills \\ Department of Geography, University College Dublin}

Rob Kitchin has outlined some of the major developments that have occurred in Geography over the last six years or so. I will select just a few areas to comment upon. My experience as an academic in Ireland is based upon my seven years at UCD. However, I received my BA and MA degrees from UCD in the 1980's and followed developments in Irish Geography in the intervening period. My views reflect this experience and is coloured by more recent changes occurring within UCD and other universities in Ireland.

Irish Geography reflects current trends in academia and wider society. The availability of research funding is a relatively new phenomenon that has accompanied a view of the University sector as an important component of the national economic strategy. However, the availability of funds has been linked to a desire to 'restructure' the University sector to 
contribute more effectively to this strategy, which includes developing closer links with private industry. This perspective is supported by a series of 'independent' reports on Irish Universities, which are increasingly regarded by many as business enterprises that should be governed and managed as such. The implications of this view are already being felt to varying degrees and, as a result, Irish third-level education and Geography are in transition.

Among those areas undergoing radical change are teaching and research. Academic geographers in Ireland have traditionally focused on undergraduate teaching. Postgraduate supervision was rare and postgraduate teaching largely non-existent. Research and its publication was an important but perhaps secondary endeavour. The undergraduate programme still occupies the bulk of collective endeavours at the departmental level. Although the intensity of teaching at this level has perhaps been reduced, the vast increase in the numbers of students has more than compensated. At the same time, postgraduate supervision/teaching has emerged and academics are encouraged to undertake research that has an international audience. The 'ideal' academic now obtains funded research to support postgraduate students that work on defined projects (often as members of a team) and who publishes in major international, peer reviewed journals. This academic international validation ensures that the researcher is aware of current intellectual activity, which will be incorporated into their teaching. According to this model, the more successful academics are in this endeavour, the more successful the Geography programme becomes. This will attract qualified students from at home and abroad and create a vibrant postgraduate environment. Students graduating from these programmes should be able to compete on the international stage for academic positions.

Academics, like any other group of workers, tend to organise their work according to real or perceived rewards. 'Old' Irish Geography completed a great deal of research on the island of Ireland and published in journals that were readily accessible and to a receptive, local audience. Individual interests guided research topics and for many the lack of equipment/personnel and/or allied colleagues limited the scope of the research. A tribute to old Irish Geography is its placement of graduates in a variety of 'critical' positions in Irish society, including teachers. Undoubtedly part of the success of 'new' Irish Geography is founded on our very large undergraduate classes, which is due in no small part to the ability of second-level geography teachers. Moreover, an important measure of the intellectual success of old Irish Geography is the number of academic'geographers in the AngloAmerican world that can trace their lineage to Irish universities.

New Irish Geography emphasises research and publication and these endeavours are closely connected to the development of postgraduate programmes. The number of supervised postgraduate research projects is now considered an important measure of academic performance. This may place the academic in an invidious position as she/he now has a vested interest in encouraging students to undertake postgraduate research with them, even if the students might receive superior training elsewhere. In Irish Geography where the staff numbers are small and there are rarely more than two academics with shared interests, it becomes a major challenge to ensure that postgraduates get the broad and intensive training required. These issues may be exacerbated where the research is funded and the academic/graduate student must seek a compromise between their interests and the requirements of the funding agency. Academics in the new Irish Geography will be rewarded for measurable productivity in terms of funding and/or research output. 
While broadly welcome, the current emphases on funding and research pitched to an international audience may have undesirable outcomes. Already, University aspirations and research funding are having an impact on the traditional academic organisation. To improve their international profile and gain additional funds, Universities are considering 'aligning' their structure with the streams of available funding. As part of this organisational 'efficiency' Universities seek to reduce academic offerings (by merging departments into schools) and identifying 'areas of excellence' for investment. Coupled with this is the desire for 'flexibility' in appointments. Ultimately this will see a transfer of academic hires toward selected areas, increased use of contract staff, off-scale appointments and the gradual devaluation of undergraduate teaching. The net effect will be to distinguish between geography as practiced in different Irish Universities, based upon their relevance to that University's strategic plan.

Similarly, the desire for increasing the international profile of geographical research in Ireland is healthy so long as it does not diminish our interest in issues that are of Irish significance and our commitment to Irish audiences. This includes academics, policy-makers and the general public. Much government funding seems to me to be strategic (for example, to fulfil EU obligations) and may divert the attention of academics from other worthy research topics. Economic prosperity has heralded very significant and ongoing changes in Irish society and its physical and cultural landscapes that need to be recorded. Some of the changes occurring now in Ireland have happened much earlier in other developed nations and have moved off the international academic radar. Nevertheless, part of this recording responsibility falls to the current generation of geographers, even if there is little contemporary academic context. The audience for this work should include the general public, for whom we have collectively produced few general geographic surveys.

There is no doubt that geography in Ireland is in flux, both in terms of its personnel and agenda. While many of the changes are positive, we should be aware of wider State and University contexts in evaluating its status and direction.

\section{David Nally \\ Department of Geography, University of British Columbia}

By way of concluding his commentary on 'Geography in Ireland in Transition' (Kitchin, 2004), Rob Kitchin guardedly intimates that 'perhaps some will think it too soon to reflect on and document Irish Geography since the new millennium' (Kitchin, 2004: 18). Far from it! We owe a tremendous debt to Kitchin for providing a critical space to reflect on the shape of our discipline and for opening dialogue on its future development. Rather than allowing this critical space to close - or worse, degenerate into a space for thought for thought's sake I'd like to append some remarks which I hope will further Kitchin's aims without necessarily travelling the same ground.

Kitchin's careful account addresses the challenges (and huge potential) of a professionally trained and technical intelligentsia in the context of 'Geography in Ireland.' However, rather less is said about the important role of the public intellectual in this context. In Kitchin's defence it might be argued that this is not a debate specific to geography, or Irish Geography for that matter - although most would surely admit that it is central to both. In what briefly follows I want to make the case for promoting the role of geography outside the 
'institutional structures' Kitchin discusses, and for regarding this task as one of the major challenges facing Irish Geography in the twenty-first century.

Geographers are by now accustomed to hearing about the 'resurgence of space' in social science and the new relevance of 'geographical knowledges' beyond the academy. Geography is suddenly sexy - although many of us are not exactly sure why. In Ireland, as Kitchin has shown, the spin-offs are immense, and are to be seen in how well the discipline has fared in attracting funding, its growing influence in policy making circles, and the sharp increase in students taking geography as a degree subject. Many excellent hours of teaching and research lie behind these developments and this hard work is surely to be commended.

That said, I am particularly struck by how seldom geographers appear in the media to discuss critically topics we have an obvious expertise in. It also seems clear to me that geographers are ideally placed to interrogate some of the world's most crucial questions, from global warming to the so-called 'war on terror.' To keep with the former example for the moment: would it not have provided enormous support to environmentalists and activists the world over if a geographer had offered a critical counterpoint to David Bellamy's damaging article, 'Global warming? What a load of poppycock!' recently published in the Daily Mail? (Bellamy, 2004). Or to take another example more specific to the Irish press: the recent referendum on citizenship in the Republic might be expected to appeal to a range of geographers interested in a variety of issues from identity and immigration to citizenship and racism. Yet, as far as I am aware, the response was almost negligible. To the people affected by these important issues - all of us - the 'resurgence of space' has had very little purchase.

No doubt the examples I have chosen are somewhat subjective and there are - more importantly - noble exceptions to the blindspots I have just listed. Notwithstanding these and other achievements, Jennifer Robinson has recently urged more geographers to consider the geography to how 'geographic knowledge is produced.' By this she means more than just 'the sites of its theories and the routes it tracks as it travels and is transported across the globe,' but also 'the places it never reaches, and the vast zones of the world which never inform its imagination' (Robinson, 2003: 400). In tune to Robinson's call, I think it is crucial for us to consider those multiple spaces marked, not by our presence, but by our absence and, in particular, whether or not Irish geographers have been able to transpose the disciplines new found cache beyond the academy into the public realm.

Accordingly, I think three principle considerations warrant more explicit attention. First, we need to ask ourselves what are the major world problems as we set off into the twentiethfirst century (there are many who believe that today's issue is nothing less than our future survival as a species - a grandiose topic if ever there was one). Second, we need to identify the central issues in these debates, and how we as geographers can make meaningful interventions. Third, we ought to identify who is empowered to make the principal decisions on these issues - on 'our' behalf - and encourage public scrutiny in these areas. In other words, it is important for academic geographers to develop strategies of engagement that work with a series of normative concerns (Dempsey and Rowe, 2004: 35).

Some might argue that this is all very well, but surely the lecture hall and the seminar room are the key sites for professional scholars to urge awareness and promote discussion. I believe this view is blinkered. For good or ill institutionalised learning has its own conventions and priorities not to mention its own privileges and closures, and it bears remembering that a university education is an opportunity presented to a fortunate few. In fact, a commitment to education (in the broadest sense of that term) actually implies nothing 
short of a social upheaval whereby the divisions and hierarchies between street and classroom melt away into insignificance.

We should properly ask, then, why is it that Irish Geography has a relatively low public profile? Can this be reversed, and moreover, is this something geographers in Ireland ought to be concerned about? Let me briefly sketch one answer to the former question and conclude with the latter.

In a recent debate in The Nation magazine entitled 'the future of the public intellectual,' the organiser, John Donatich, confessed that he worried about making the slip, 'the future of the public ineffectual' (Donatich et al., 2001). In actual fact, as Donatich quickly understood, the malapropism is entirely relevant to the topic at hand. To consider the public role of the professional scholar invariably means questioning the yawning gap between expertise and accessibility. This difficulty is no doubt related to the specialised languages we adopt, and the high levels of abstraction we typically work in. ' $\mathrm{Be}$ as obscurantist as you can decently get away with,' seems to be an unstated mantra of much disciplinary work - geography included (see Eagleton, 1999; 2003). From a purely practical perspective, it is a taller order to encourage and facilitate public discussion if, for example, one insists on discussing Iraq via Irigaray.

Leaving the vagaries of theory aside, there also seems to be a common presumption and fear - that 'one may become more and more public and less and less intellectual' (Eagleton, 1999). Terry Eagleton suggests that this is because many scholars mistakenly imagine that 'intellectual' means 'frightfully clever,' and, of course, it's logically impossible to be frightfully clever and popular at once (who could possibly understand you?). In fact, 'the word 'intellectual' is a job description, not a commendation.' 'There are,' as Eagleton reminds us, 'dim-witted intellectuals just as there are incompetent chefs' (Eagleton, 2004). There is nothing inherent to our job description which precludes a more public role (on the contrary), nor is there any reason to believe that geographers cannot be to the forefront of current debates in Ireland and beyond: the discipline is clearly relevant and unquestionably necessary. In this sense, I think, audacity rather than expertise is needed. For it takes a certain sort of irreverent love 'to be of the academy but to have [ones] back turned to it, ready to speak to an audience greater than one's peers' (Donatich et al., 2001).

It also takes a considerable amount of time, and to be fair I suspect more mundane matters make the last position the exception rather than, the rule in Irish Geography. Kitchin's commentary rightly draws attention to the many institutional pressures facing Irish geographers: high staff student ratios, increasing research pressures and so forth. The list is familiar and troubling. In this climate can geographers reasonably be expected to delegate already precious time to public debates, media discussions, and community forums?

This leads me to my final point. Although there are no easy answers to this question, if we believe that first, a broad-based education needs to be assiduously cultivated, and second, that the discussion of today's important debates cannot be left to the corporate media and its spin doctors, then like George Bernard Shaw when asked what he felt like on his ninetieth birthday, we can only respond by saying: 'Considering the alternatives ...' 


\section{Acknowledgements}

I wish to thank Mary Gilmartin for inviting me to respond to Rob Kitchin's commentary and Denis Linehan for his remarks on an earlier version of this paper.

\section{References}

BELLAMY, D. (2004) Global warming: what a load of poppycock, Daily Mail, 9 July.

DEMPSEY, J. and ROWE, J. (2004) Why poststructuralism is a live wire for the left, In: Kitchin, R. and Fuller, $\mathrm{D}$. (eds) Radical theory/critical praxis: making a difference beyond the academy. Vernon: Praxis (E)Press. Available at <http://www.praxis-epress.org/rtcp/contents.html>.

DONATICH, J., JACOBY, R., ELSHTAIN, J.B., CARTER, S., GANS, H., JOHNSON, S. and HITCHENS, C. (2001) The future of the public intellectual: a forum, The Nation, 12 February.

EAGLETON, T. (1999) In the gaudy supermarket, London Review of Books, 21(10), 3-6.

EAGLETON, T. (2003) Afier Theory. London: Allen Lane.

EAGLETON, T. (2004) Too clever by half: A review of Frank Furedi's 'Where have all the intellectuals gone?', New Statesman, 13 September.

KITCHIN, R. (2004) Geography in Ireland in Transition, Irish Geography, 37(1), 15-19.

ROBINSON, J. (2003) Introduction: cultural geographies beyond the west, In: Anderson, K., Domosh, M., Pile, S. and Thritt, N. (eds) Handbook of Cultural Geography. London: Sage, 400-404.

\section{Denis Linehan \\ Department of Geography, University College Cork}

At the heart of Kitchin's commentary on the condition of Geography in Ireland is a call to invest in the space of the discipline. Many of the challenges he identifies regarding research, teaching and promotion are in fact faced by all academics. In the face of those challenges Geography - with its strong input from second level and its association to environmental and spatial policy - is apparently more robust than our some of our academic peers. Nevertheless, Kitchin is correct in seeking to spark a debate about where we are, what we are all about and where we are going. The academic environment in Ireland has become more competitive and more divisive, and we would be foolish to ignore the fact that now, more than ever, our identity as discipline needs strengthening.

At the time I first encountered Kitchin's paper, I read two other pieces about geography and the university. One is an essay I found in the papers of Charlie $O^{\prime}$ Connell, the first Professor of Geography at UCC. In the preface to Eruption - a journal of the UCC Geographical Society published for the first time in 1971 - O'Connell congratulated his students on their interest in 'the problems of our time' but he concluded that 'here in Ireland the earth we tread on is firm and permanent - a true terra firma...life goes on quietly enough, little changes. Things will always be as they have always been' (O'Connell, 1971: 3). When I read this I wondered what kind of conversation Kitchin and $O^{\prime}$ Connell might have had around a dinner-table! These thoughts on transformation were pulled into sharper focus on reading the second article, 'A new breed of President', published in UCC News. In this, Tánaiste Mary Harney outlined her ideas on university reform (Hamey, 2004). She argued that tenure was handed out too easily, that the university is an 'ideas factory', one of the 'key drivers of economic success in Ireland' and that we all needed to be 'global players' (Harney, 2004).

Elsewhere, Harney has revealed her own particular perspective on geography. In a way that almost presents as direct critique of $O^{\prime}$ Connell, she has remembered 'her country in the 
1980s as an inward-looking place, locked into age-old doctrines and rivalries' and that in competing with the challenges of EU enlargement and building a competitive economy 'geography has to be irrelevant' (Baker, 1999). 'Geography,' as Harney uses it here, is not understood (at least one hopes) as the discipline, but rather as the physical limits of the island. But it suggests that as science and technology rise to support the 'national interest' that the established concerns of our discipline and its organisation is more vulnerable that we might be prepared to acknowledge. Mobilising national interest in the university is a key mechanism for advancing one's interest within the increasingly tarnished ivory tower. Other disciplines have already colonised our traditional areas of expertise, and in some cases, harvested our FTEs! University administrators can look into any Geography department and seek to cherrypick both the best staff and most successful research areas and reconfigure them in new schools that seem to best meet the demands of the research-grant economy. For nongeographers looking in, there is nothing sacred about the current configuration of Geography departments and our combination of environmental and social research and teaching interests.

To respond, we need to be less modest about the value of those combinations that make Geography so distinctive and so attractive to students. We need to lay claim to the elixir that makes the geographical imagination a vivid and flourishing instrument of investigation and enquiry. In our Universities, in the media, and in the academy, we need to make Geography more visible. Nobody else is going to do it for us. In face of university restructuring, the apparatuses of the annual conference and journal become a more significant part of that goal. As our departments come under increasing pressures, and as new appointments have to be secured, we will have a stronger position if Geography is seen as vibrant, strategic and critical at the national level. We have collective control over both the journal and the conference. They serve as an important vehicle to progress the discipline. Over the last number of years, there have been improvements in how both are organised. That needs to continue. If the motivation is there, ways to strengthen the participation in the conference and the production of the journal can be found. As Kitchin makes plain, we are no longer on terra firma, and if the journal and the conference go into decline now, we can kiss good bye to the discipline, and perhaps our departments, in Ireland.

\section{References}

BAKER, S. (1999) Mary Hamey's Ireland: High-Tech Hibemia, Businessweek Online, November 8. Available at <http://www.businessweek.com:/datedtoc/1999/9945.htm> [accessed 12 July 2000]

HARNEY, M. (2004) A new breed of President, UCC News, October, 1-3.

O'CONNELL, C. (1971) Preface, Eruption, 1, 3.

\section{Seamus Grimes \\ Department of Geography, National University of Ireland, Galway}

It would be difficult to disagree with many of the points raised by Rob Kitchin in his summary of what has been happening in Irish Geography in the past few years. In responding to his invitation to reflect on where geography in Ireland is going in the future, it is important to evaluate the recent few years of relative success and dynamism within a longer period of geography's evolution in Ireland. Clearly the most recent period has seen a significant improvement in the availability of research funding, which has been successfully exploited by many geographers in Ireland, and we are now entering a period in which geography in this 
country is becoming increasingly internationalised and integrated into developments of the discipline in other parts of the world, and particularly the English-speaking world. This, of course, is not a new phenomenon, but its scale and intensity marks a shift in the dynamic which has been shaping the development of geography in Ireland. It is an opportune moment, therefore, to reflect on the direction in which geography in Ireland is going. While we should celebrate the successes of recent years, it is even more important that we ensure that our future direction is founded on a firm intellectual basis.

Rob Kitchin contrasts what he refers to as the 'empiricism' of geography in Ireland in recent decades with the more recent engagement with social theory. It is true to say that much of the geography produced in Ireland during earlier stages was heavily influenced by scholars working in historical geography, and that much of this work focused on aspects of the uniqueness of Ireland's landscape and history. Not surprisingly, the recent period is characterised more by work examining aspects of Ireland's increasing integration into a globalised world. This period has also seen an increasing internationalisation of the work of geographers in Ireland, both in terms of their involvement in international research networks and through an increasing proportion of their work being published in international journals. An additional factor contributing to this internationalisation process is that an increasing number of those teaching and researching in Irish Geography departments come from a wider international background.

While all of these factors have been contributing towards our ability to produce what is regarded as 'world class' geography, we should also be wary of some tendencies in the discipline towards the development of a generic and rather bland form of geography, lacking in originality.

There is nothing radically new about geography's development in Ireland being based on integrating ideas from many other places. The early stages of geography's development here reflected a very close integration with what was happening particularly in geography departments in England, Wales, and Scotland, with many of the early geography chairs and lecturers coming from these departments. At that time Ireland's emerging geography departments were seen as possible staging posts in the early careers of UK geographers. A further element in the cross-fertilisation of ideas resulted from the many young Irish geographers who went abroad for their postgraduate studies. Some of these returned to contribute towards the development of geography in Ireland, while others have made major contributions to the discipline's development in their new countries. It is clear, however, that we are now entering a period of even greater integration with a much wider world of geography, something which presents great opportunities for the future development of the discipline in Ireland.

In reflecting on the most recent period of rapid growth and success, it would be useful to consider the impressive record of contributions to the discipline's development which have already emerged from this relatively insignificant country. I am thinking in particular of the major contributions which have been made by scholars such as Anne Buttimer and David Livingstone. One could argue that there is not very much in their work that is distinctively Irish, and that in both cases they have been major integrators of ideas from other places. However, because of the significant impact which they have made toward shaping the discipline's development internationally, reflecting on the nature of their contributions may have much to offer us as we seek to chart the future of geography in Ireland. 
The work of Buttimer and Livingstone provides us with a number of useful guidelines which can help to ensure that we develop an intellectual environment within our departments which succeeds in producing scholars of an equivalent calibre in the future.

It could be argued that among the reasons why both of these geographers have had so much influence on the discipline generally, is that both of them have been highly original in their thinking, and have helped to challenge many geographers to reflect more deeply on the development of the discipline. In integrating a wide range of ideas into the discipline, both of these scholars adopted a highly critical perspective based on a strongly independent form of thinking. I would suggest that one of the main reasons for this arose from the fact that both scholars were deeply influenced in their intellectual formation by a serious engagement with the work of philosophers. Despite the calls by geographers like David Smith for a greater engagement between geographers and philosophers, the most recent period appears to be more dominated by the influence of social theory.

This more recent involvement with social theory also appears to be closely associated with a greater degree of the politicization of geography than was the case heretofore. While Livingstone's work in particular has made us more aware of the political nature of knowledge construction in geography, an engagement with the work of philosophers can help not only to deepen our understanding of the 'human' in geography, but also to develop a more critical perspective towards integrating elements of social theory into geography. Developing such a critical perspective is, in my view, the greatest challenge which geography in Ireland faces today, if we are to come close to matching the impressive contributions which have emerged from this country to date.

\section{Pádraig Carmody \\ Lecturer in Geography, St Patrick's College, Drumcondra.}

As a recently returned emigrant and newly appointed geography lecturer, Rob Kitchin's commentary raised a number of issues for me. I have not been an academic geographer in Ireland long enough to comment on the transition which he identifies. However, having studied (at Trinity and the University of Minnesota) and taught (University of Vermont, and St Patrick's College, Drumcondra) in both the Irish and US systems, I thought it might be interesting to compare and contrast the strengths and weaknesses of the two systems.

Internationally, academic, and particularly human geography is dominated by an AngloAmerican axis. This is evidenced in a variety of ways: many of the top economic and social geographers in the US are originally British. There are too many to name but they include Kevin Cox, Kim England, Victoria Lawson, Jamie Peck, David Harvey - the list could continue for many pages. There are also several prominent Irish-born geographers. I once discussed this with one of my $\mathrm{PhD}$ advisors in the US (who was, perhaps not coincidentally, from England) and he explained to me that people coming out of the British and Irish systems were at a competitive advantage, compared to their American counterparts. I will explain, but allow me to digress.

Geography is a minority discipline in the United States. The relative lack of an (external) colonial history in the United States meant there was not the same impetus given to the discipline as through the explorers of the Royal Geographical Society in Britain. While some of the old, private, East Coast 'Ivy League' universities did have geography departments, many of these were closed in the wake of the closure of the geography department at Harvard. 
As a result, the main centres of geographic research in the US tend to be in the great public universities, such as UC Berkeley, Penn State and the University of Wisconsin. American, along with UK, Geography dominates academic geography internationally. There are some excellent graduate (post-graduate) programmes in the US and the scale of the country means that the Association of American Geographers (AAG) is the largest and most prominent of the international associations. However, there are continuing problems with geographic education there. These start with the fact that geography, for the most part, is not taught in high (secondary) schools. There are now attempts to reintroduce it, but even if this happens it will take a long time for this to bear fruit (I remember grading one essay as a teaching assistant where the writer [who had lived for some time in Australia] expounded 'European countries like Hong Kong and Australia...'. Countries which were consistently named correctly on map quizzes were Iraq and Haiti, for some reason!).

There are also other structural problems at undergraduate level in the US. There has recently been a debate in the newsletter of the AAG about how to increase the teaching of geography at liberal arts colleges (the elite, private, undergraduate teaching colleges which form a 'pipeline' into the Ivy League and graduate education in the US). Only a handful of these have geography departments; perhaps the result of a 'trickle down' from the Ivy League. Another aspect of undergraduate geography in the US is that students specialise later than they do in the Irish and UK systems. All students must fulfil certain requirements in maths and sciences for example, before 'majoring' in geography. All of this means that Ireland and the UK tend to produce better undergraduate students in geography. I personally have found teaching students here to be easier because of that, although there are of course many, many excellent geography undergraduates in the US. Also there is less pressure to 'edutain' in Ireland, given the fact that salaries and promotions in the US are often linked to student evaluations. That said, Irish universities can probably never hope to compete with range of course offerings for undergraduates, or scale of resources of the major US departments, which greatly facilitate their graduate programmes. The difference in resources means that students at the bigger departments in the US have access to a much broader and more diverse discipline. Nonetheless, I think undergraduate teaching in Ireland is one of the major successes of the discipline.

In terms of research and staffing, I think that geography in Ireland is becoming more diverse, while maintaining its traditional strengths. This is to be welcomed. Diversity is an issue which is pre-occupying some of the staff here at St Patrick's College. As a predominantly teacher training college, this issue affects us perhaps more immediately than colleagues at other institutions (About a quarter of students at St Patrick's take academic geography for their $\mathrm{BEd}$ or BA). I recently visited some primary classrooms in Dublin where the student body is changing rapidly. The trend towards increased diversity will only continue, and a much more diverse college student body is on the horizon. The challenge for us as educators in response to this is to diversify our curricula and empower our students to benefit from the many intellectual, cultural and social benefits that human diversity, in all its forms, brings.

Ireland has a long history of global interaction, prior to and after incorporation into Empire. Ironically given our physical, but not historical, geography the level of interaction between not only Northern and Southern Irish Geography appears low (to over-generalise as the North looks East and the South increasingly West?), but the level of interaction between Geography in the Republic and the UK also appears low. This seems to be an underdeveloped, though improving, relationship. We have a major centre of geographic research in the world, if not at our doorstep, in our neighbourhood. Building relationships with UK Geography and 
more networking within Geography in Ireland should help us to improve our post-graduate education. Recent initiatives, such as the Geography post-graduate consortium, are to be very much commended in this regard. With an increasingly diverse population, and particularly student population, it will also be important to look further afield and lead in the development of relationships with African, and perhaps Eastern European Geography, in particular.

As a major site, and increasingly sender of foreign direct investment ('rebounding globalisation') and magnet for immigrants; and with the concomitant deepening intensity, extensity, velocity and impact of global interconnections it has perhaps never been a better, or more apposite, time to be a geographer in Ireland. It is up to us to make the case to government and other funders of the competitive advantage and increasingly vital role which geography has to play. By tapping the diversity, access to increased funding, traditional strengths and vitality of the country and discipline, Geography in Ireland is poised to equip students to understand a rapidly changing world and make international contributions, over and above its previous seminal achievements.

\section{Mark McCarthy \\ School of Humanities, Galway-Mayo Institute of Technology at Galway}

In 1945, Estyn Evans was awarded the first Chair of Geography on the island of Ireland (Smyth, 2000). Almost sixty years later the discipline has grown in considerable strength and its conventional boundaries have extended into exciting new teaching and research areas such as Heritage Studies (see Graham et al., 2000). While it is clear from Kitchin (2004: 15) that there has been 'a major transition in the state and development' of Geography since the dawning of the new millennium, one area that escapes his timely and welcome commentary is the new academic campaign to establish elements of the discipline in the institute of technology sector in the Republic. This sector has grown considerably since the establishment of regional technical colleges in the 1970s: enrolment numbers have grown ten-fold since 1975 , and the sector now accounts for 48 percent of admissions to Higher Education in the Republic. In recent years, Humanities has made impressive inroads into many institutes, with the establishment of degree and certificate courses in, for example, tourism, heritage studies, and cultural studies.

While 'Ionely' geographers are actively involved in the delivery of Humanities programmes in the Galway, Dublin and Dundalk institutes, it is my intention in this short piece to comment on the emergence of Geography on the curriculum of the four-year BA (Honours) in Heritage Studies degree programme that is delivered at both the Galway and Castlebar campuses of Galway-Mayo Institute of Technology (GMIT). My positionality is that of a historical geographer operating outside the conventional departmental structures of the discipline in Ireland, but one who nonetheless retains robust networks with the Irish and international professional geographical community. Founded in 1972, GMIT since the mid1990 s has broadened the remit of Geography beyond its traditional home within the universities of Ireland. The Heritage Studies programme was originally established in 1995 at both the Galway and Castlebar campuses of GMIT as a two-year National Certificate programme and a one-year add-on National Diploma - both of which were validated by the National Council for Educational Awards (NCEA). In 2000 validation was granted for degree level awards, thus enabling students to graduate with a BA in Humanities in Heritage Studies following a total of four years of study. The four-year BA (Honours) in Heritage Studies 
programme run by GMIT's School of Humanities seeks to provide students with an advanced knowledge and understanding of the theories, concepts and methodologies utilised in what is by nature a multi-disciplinary field concerned with the position of the past in the present. In addition to courses in History, Archaeology, Languages, Business, and Information Technology, a series of mandatory Geography courses are also offered in areas such as Historical Geography, Rural Geography, Physical Geography, Biogeography, Tourism Geography, and Urban Planning. Fieldwork also forms a vital component of course work. In 2004 the Heritage Studies programme at Galway was accepted by the Registration Council for Secondary Teachers for teaching purposes, thus enabling graduates to proceed to the National University of Ireland's Higher Diploma in Education teaching qualification for Leaving Certificate Geography and History. Graduates who complete the Heritage Studies programme at Castlebar are also eligible to proceed to the teaching qualification for Leaving Certificate Geography. GMIT's links with the geographical community have also been bolstered by the fact that eminent geographers have acted as External Examiners to the undergraduate and postgraduate Heritage Studies programmes.

Although the teaching load in the institute sector is much heavier than in universities (lecturers are employed on the basis of 16-18 contact hours per week), the smaller class numbers that characterise the institute of technology sector has advantages when it comes to training students in geographical methods. In an age in which some Geography Departments are scrapping the requirement for undergraduates to produce dissertations based on original enquiry, dissertation research remains a mandatory component of the BA (Honours) in Heritage Studies degree. Smaller class numbers also have the added benefit of enabling GMIT students to embark on several field excursions throughout the course of their undergraduate careers. While Geography in Ireland moves away from its empirical traditions and increasingly embraces social theory, I am disappointed and somewhat alarmed at the reluctance on the part of some lecturers to organise fieldtrips for their students. Learning geography in a packed lecture theatre is all very well, but no student's geographical education is really complete without having undertaken fieldwork - a geographical tradition that extends back to the pioneering work of Pestalozzi, Ritter, Geddes, Wooldridge, Mackinder, Fleure, Stamp, and Sauer (Stoddart, 1988: 144-6). As a teaching aid, I sincerely believe that fieldwork is a far more effective aid to geographical understanding than any number of theoretically-based lectures, and that concerns about logistical issues such as excessive class sizes, safety, cost, and time can be easily overcome with a little forward planning and initiative.

Despite the special emphasis on teaching and training, and the absence of an extemal assessment of research quality like the British RAE, research has emerged as a core activity within the institute of technology sector since the passing of the 1992 and 1999 RTC Acts and the 1999 Qualifications (Education and Training) Act. One consequence of this is the emergence of a postgraduate research community within the institute sector. Research is seen as vital for technological innovation and can also lead to the creation of start-up companies that can stimulate regional development and create employment opportunities. However, total postgraduate numbers registered in the sector only account for a mere 2 percent of postgraduate enrolment nationally (with the majority of these registered in the Science and Engineering disciplines and drawing funding mainly from Enterprise Ireland and Science Foundation Ireland). To date, institutes of technology have had minor success in bidding for PRTLI funding and have been forced to rely heavily on collaboration with the 'centres of excellence' that have emerged in universities. Nonetheless, the numbers of Humanities postgraduates in the institute sector is steadily growing. Since 2001 , for example, the number 
of postgraduates taking the MA (by research) in Heritage Studies in GMIT has risen from zero to ten. In addition to the PRTLI, funding for postgraduates has also been successfully sourced from Strand 1 of the Department of Education and Science's Technological Sector Research Initiative. As a result of this new research capacity, the past couple of years have witnessed a Heritage Studies presence at the Annual Meetings of the Irish Postgraduate Training Consortium for Geography at Navan and Glencree respectively. These links have been further consolidated by the nature of the research conducted by GMIT personnel.

Whilst there has been a blurring of the boundaries between the two elements of the binary system in recent years, the recently-published OECD (2004) report on Third Level Education in the Republic of Ireland recommends that the distinctions remain. How Geography can expand in the institute sector in the face of a climate of budgetary cutbacks, altering demographics and excess capacity remains to be seen. On the evidence to date, however, I feel that important beginnings have been made, and that the expansion of elements of the discipline into non-traditional areas is a healthy development, coming at a time in which the faculty and departmental structures of certain universities are undergoing review by steering groups. Overseas, Geography has made significant inroads into non-traditional areas in places such as the UK, where Geography now thrives in some of the new universities that emerged from polytechnics, and the USA, where a dozen or so liberal arts colleges, on a weighted basis, "have proven to be the most fertile grounds for laying the undergraduate foundation for academic geographers' (Bjelland, 2004: 334). The institute sector in the Republic of Ireland, I believe, has the potential to contribute significantly to the discipline's resilience in this new millennium by creating multidisciplinary programmes with a geographical element. This in turn has the potential to open up significant employment opportunities to Irish geographers who compete for management, lecturing and research posts in what is a very limited and highly contested staffing market.

\section{References}

BJELLAND, M.D. (2004) A Place for Geography in the Liberal Arts College?, The Professional Geographer, 56(3), 326-36.

EXPERT WORKING GROUP (2003) Institutes of Technology and the Knowledge Society: Their Future Position and Roles. Dublin: Council of Directors of the Institutes of Technology.

GRAHAM, B.J., ASHWORTH, G.J. and TUNBRIDGE, J.E. (2000) A Geography of Heritage: Power, Culture and Economy. London: Arnold.

KITCHIN, R. (2004) Comment: Geography in Ireland in Transition, Irish Geography, 37(1), 15-19.

MCCARTHY, M. (in press) Ireland's Heritages: Critical Perspectives on Memory and Identity. Aldershot: Ashgate.

OECD (2004) Review of National Policies for Education: Review of Higher Education in Ireland. Paris: OECD.

SMYTH, W.J. (2000) Putting twentieth century Irish Geography in Context: A Personal Perspective, Chimera, 15, 1-15.

STODDART, D.R. (1988) On Geography and its History. Oxford: Basil Blackwell. 


\section{Jim Hourihane \\ Head of the Geography Department, St Patrick's College, Drumcondra, Dublin 9}

Being one of the 'thirty year' veterans who has been involved within the Ireland and the Geography in Ireland that Rob Kitchin reflects on in his timely and stimulating commentary, I would like to suggest that we need to attend, as well as to the issues he raises, to two further aspects of Geography in Ireland. Firstly, we need an ongoing awareness that we should never lose sight of the primacy of teaching Geography. Secondly, Geography in Ireland needs to be contextualised within three levels - primary, second level and third-level and that all three are inter-related to a far greater extent than is usually thought to be the case.

I would suggest that Geography in Ireland has gone through several cultural turns over the last thirty years and that its current state of good health pervades all three levels at which it is taught, learned and experienced.

The Irish fascination with the past - and this applies to both our physical and cultural landscapes as much as to the events played out on them - has helped, even caused us to be placeful people. Being locality-bound had both its advantages and disadvantages. Intimate knowledge of localities brought with it security and joy, as well as boredom and introversion. Yet, in spite of this long-lived containerisation of people's lives within the island of Ireland for a large part of the twentieth century, there was also an imagined world that co-existed with the local. The 'Capes and Bays' approach to teaching and learning Geography did lead to the memorisation of vast quantities of material. It is also a fact that pupils, students and the public at large knew the geography of their world far better than their contemporaries today. This approach to teaching Geography in Primary Schools (ages 4 to 12 approximately) was replaced by the 1971 Primary School Curriculum - known intriguingly for the next thirty years as the 'New Curriculum'. This curriculum had several principles underpinning it, most notably:

- A concentric approach that was firmly rooted in the child's immediate environment;

- An approach that was integrated with the other areas of the curriculum;

- Discovery methods that included first-hand investigative and project work;

- An emphasis on the teachers being highly selective when devising their schemes of work;

- The introduction of a greater air of reality and variety into primary school geography.

The replacement of this curriculum began in the late 1980s when the National Council for Curriculum and Assessment (NCCA) established a curriculum committee for Social, Environmental and Scientific Education (SESE) that was charged with establishing a new curriculum for the three components of SESE i.e. Geography, History and Science. The three central planks of SESE would be knowledge, skills and attitudes. In the case of Geography its concern was viewed as 'developing the child's understanding and appreciation of the world in which he/she lives'. The content of the current curriculum (published in 1999) in primary schools is now presented in three strands:

- Natural environments

- Human environments

- Environmental awareness and care 
Particular emphasis is placed on skills and concepts development such as developing a sense of place and space; using maps, globes and graphical skills; using geographical investigation skills.

Just as the early 1970 s were a significant landmark in the development of Geography in primary schools so too the late 1960s marked important changes in the teaching of Geography at second level. These changes were due in no small part to the teachers of Geography who founded the Association of Geography Teachers of Ireland (AGTI) in 1962. This association energised the teaching of Geography and encouraged the adoption of approaches being promulgated by more enterprising teachers who were making Geography at second level less bookish and more interesting and relevant. A new Leaving Certificate syllabus was introduced in 1967 - this gave a further impetus to the growing relevance of how Geography was measured. Further syllabus changes in 1973 for the Intermediate Certificate and in 1975 for the Leaving Certificate did not encourage the methodological changes that were both desirable and necessary. Skills and concepts were encouraged from the late 1970s onwards but, very significantly, the numbers of students choosing to study Geography at Leaving Certificate level began to diminish quite sharply. Professor Des Gillmor suggested a number of possible reasons why students were opting not to study Geography - he concluded that it was not possible to offer simple explanations; rather the reasons lay in a complex multifactor situation. The image and status of Geography as a subject, the broadening of the curriculum, third-level entry requirements, examination grades and the syllabus and its teaching were all felt to be part of the lack of success of Geography in attracting students.

Since the late 1990s Geography has grown hugely in its popularity as a Leaving Certificate subject. In recent years approximately one out of every two of the 60,000 students taking the Leaving Certificate studies Geography. A revised Leaving Certificate syllabus was introduced in September 2004 for first examination in June 2006. This new syllabus aims to develop an understanding for students of the inter-relationships in the human and physical environments at both national and international levels. Very significantly, it introduces a core area of study for all Leaving Certificate students - The Geographical Investigation - that will allow them to experience the practical application of the core geographical skills that are central to all units of the new syllabus.

And where, one may ask, does one position the teaching of Geography at third-level within what I am suggesting is a continuum that ultimately draws its synergies from each of the three component parts? Rob's commentary rightly states that Geography as a discipline has been a popular among students since the various departments were founded. It has never been more popular, I would suggest, than it is today and its popularity is more than a numeric popularity. Its fortunes and successes lie in no small part to it being well taught. Let's not be too Irish and celebrate lives only at funerals. The standard of teaching at third-level is generally very high. Geography is seen as a relevant discipline that also has value(s). By and large it interests students and above all it enjoys the happy, almost singularly so, attribute of being experiential. Geography's 'sexiness' - for ultimately that is what attracts students to it - lies in the areas that Rob has identified in his commentary. It is certainly viewed as a valuable resource by government and semi-state agencies and contributes to debates at national, regional and local policy levels.

We need to be alert to its future status. Rob identifies as a potential challenge 'the proposed institutional restructuring within some universities... [wherein] the role and position of geography institutionally, intellectually and financially is likely to be affected by any 
institutional restructuring, particularly if departments are merged or assigned to new faculties...'. As one of those who argued, thankfully successfully, at NCCA committee level when the new SESE programme was being structured, for the survival of Geography both as a discipline and as a name, I share his anxieties. It was mooted by a few members of that committee that Geography would be replaced by the phrase 'A sense of the world' and that the future of Social, Environmental and Scientific Education for Irish primary schoolchildren would be shaped by a loose amalgam of related areas, rather than the three traditional disciplines of Geography, History and Science. The lessons of attempted restructuring have already been identified at one level of the continuum that I regard as Geography within the Irish educational system.

Rob suggests that 'perhaps a workshop needs to be organised that brings together geographers from across the island to discuss the relationships between them and to construct some kind of shared future for the discipline'. I would urge that the workshop becomes a fullblown conference on the 'Place of Geography in Ireland'. It would provide a forum for all stakeholders who have an interest in the discipline. It would also allow us to 'think about and celebrate how far we have come in such a short space of time'. We need, I would suggest, to reflect and be aware of just how well Geography is taught - not just at third-level but from the very beginnings of the teaching continuum (with infants who are on average four years of age) when children first begin to experience Geography. From these early beginnings, through primary school and on to second-level and eventually third-level students should be encouraged to look on Geography as a subject, as a discipline and perhaps even as a career path. They can only do so if we place good teaching of Geography at the top of the strengths and needs of the discipline. 